\title{
RITUS TIBA MEKA ORANG MANGGARAI DAN RELEVANSINYA DENGAN NILAI-NILAI KARAKTER
}

\author{
${ }^{1}$ Sabina Ndiung, ${ }^{2}$ Gede Wira Bayu \\ ${ }^{1}$ Program Studi PEndidikan Guru Sekolah Dasar Universitas Katalik Indonesia Santu Paulus \\ Ruteng \\ 2Jurusan Pendidikan Dasar Universitas Pendidikan Ganesha \\ Email punyaku79@gmaill.com ${ }^{1}$, wira.bayu@undiksha.ac.id ${ }^{2}$
}

\begin{abstract}
ABSTRAK
Masyarakat Manggarai memiliki kebiasaan yang khas dalam tata cara penyambutan tamu yang berperan untuk mempererat persaudaraan dan memupuk silaturahmi. Tata cara penerimaan tamu ini dalam tradisi orang Manggarai disebut ritus tiba meka. Meka yang disambut dengan ritus ini biasanya berlaku bagi tokoh pemerintah, tokoh masyarakat, dan tokoh agama. Dalam penyambutannya diwakilkan oleh tua adat yang disebut sebagai laro jaong dan letang temba yaitu sebagai juru bicara dan perantara atau yang mewakili warga yang ada dalam satu kampung dengan tamu yang datang. Ada enam tahapan tata cara tiba meka orang Manggarai yaitu Reis tiba di'a (penyambutan dengan baik); raes agu raos cama laing (berbagi suka cita dan kebersamaan); pandeng cepa (lebersamaan jasmani dan rohani); inung waekolang (minum bersama sebagai tanda keakraban); tegi reweng (meminta peneguhan/motivasi); dan wali di'a (mohon keselamatan untuk tamu). Sementara, nilai-nilai karakter yang terkandung dalam acara ritus tiba meka adalah keterbukaan, keakraban, kerendahan hati, kehormatan, tanggung jawab, kepedulian, dan sopan santun.
\end{abstract}

Keywords: ritus tiba meka, nilai-nilai karakter

\begin{abstract}
People in Manggarai have a unique tradition in the procedure of welcoming the guest that be role playing of solidifying brotherhood and foster hospitality. This procedure of welcoming the guest in the Manggaraian tradition is called tiba meka rite. The guest welcomed with this rite commonly occurs for the government figure, public figure, and religious leaders. This welcoming ritual is commonly represented by an old custom that is called as laro jaong and letang temba, they are, as spokesman and intermediary or reprentative of all the villagers with the guest coming. There are six steps for the tiba meka rite in this regency. Those are 1) Reis tiba di'a (welcoming the guest), 2) Raés agu raos cama laing (joyful sharing and togetherness), 3) Pandeng cepa (physical and spiritual togetherness), 4) Inung wae kolang (familiarity drinking), 5) Tegi reweng (asking suggestion); and 6) Wali di'a (guest's safety asking). Moreover, the charater values contained in the tiba meka rite are openness, familiariy, modesty, honor, responsible, concern, and politeness.
\end{abstract}

Keywords: character values, tiba meka rite

\section{PENDAHULUAN}

Manggarai merupakan sebuah wilayah di bagian barat pulau flores. Daerah ini terdiri dari tiga kabupaten yaitu kabupaten Manggarai yang beribukota di Ruteng, kabupaten Manggarai Barat dengan ibukota Labuan Bajo, dan kabupaten Manggarai Timur ibukotanya 
Borong. Manggarai memiliki tradisi khas dalam penyambutan meka (tamu). Tradisi tiba meka sudah ada sejak peradaban kehidupan masyarakat Manggarai yang bertujuan menghargai sesama. Seperti halnya ketika Presiden Joko Widodo mengunjungi Labuan Bajo, Kabupaten Manggarai Barat, Nusa Tenggara Timur. Setiba di Bandara Komodo di Labuan Bajo pada Rabu (10/7) pukul 14.00 Wita, Presiden Jokowi yang datang bersama Ibu Negara Iriana Joko Widodo diterima secara adat berupa ritual tiba meka (Suwarta, 2019).

Dalam konteks budaya Manggarai, ritus tiba meka merupakan tradisi yang dilakukan secara turun temurun yang merupakan bagian dari kearifan lokal. Hal ini sejalan dengan pandangan Riyanto (2015:28-29) yang menggambarkan bahwa kearifan lokal merupakan filsafat yang hidup di dalam hati masyarakat, berupa kebijaksanaan akan kehidupan, way of life, ritus-ritus adat, dan sejenisnya. Selanjutnya Riyanto mengemukakan bahwa kearifan lokal memiliki karakter yang dekat dengan locus (tempat), yang darinya ditarik ajektif, local (yang berkaitan dengan tempat) atau wilayah yang mengurai suatu kebijaksanaan khas. Kebijaksanaan berupa produk relasionalitas manusia dengan alam yang merupakan serangkaian relasi sehari-hari manusia yang berlanjut dalam cetusancetusan kesadaran yang mendalam. "locus" dalam kearifan lokal (local wisdom) merupakan produk berabad-abad yang melukiskan kedalaman batin manusia dan keluasan relasionalitas dengan sesamanya serta menegaskan keluhuran rasionalitasnya. Dalam konsep antropologi (Kartawinata, 2011), kearifan lokal dikenal pula sebagai pengetahuan setempat (indigenous or local knowledge), atau kecerdasan setempat (local genius), yang menjadi dasar identitas kebudayaan (cultural identity).

Globalisasi telah memaksa setiap orang untuk mematuhi tuntutannya, sehingga kebudayaan di dunia menjadi seragam, materialisme, westernisasi dalam pola berpikir, berperilaku, dan material. Fenomena saat ini juga, kebanyakan peserta didik tidak lagi ramah, sudah tidak lagi menyapa sesamanya, sanak saudara, guru, orang tua, ataupun siapa saja yang dijumpainya bahkan orang-orang yang sedang bertamu ke rumahnya. Hal demikian ditambah lagi dengan realitas karakter manusia Indonesia yang tidak sesuai dengan nilai-nilai luhur bangsa. Seperti dalam kajian Lubis dan Koentjaraningrat (Sarbiani, 2015) bahwa pada kenyataannya menunjukkan bahwa mentalitas dan karakter manusia Indonesia masih terlihat dalam kehidupan masyarakat. Lubis mengatakan bahwa manusia Indonesia umumnya bermental munafik, enggan bertanggungjawab, berjiwa feodal, percaya takhayul, artistik, berwatak lemah, boros, bukan pekerja keras, suka mengeluh, mudah dengki, suka sombong, dan tukang tiru. Sedangkan Koentjaraningrat cenderung melihat manusia Indonesia memiliki sifat yang meremehkan mutu, suka menerabas, tidak percaya diri, tidak berdisiplin, dan suka mengabaikan tanggung jawab (Sarbaini, 2015). Orang Manggarai sendiri juga memiliki indikator-indikator perilaku yang sering mbeis (meremehkan), mangkong (menuduh), dan pocu (menjelekkan) sesamanya. Menurut Lasmawan (2016) globalisasi semakin mengikis kebudayaan bangsa karena terjadi akulturasi kebudayaan dengan budaya asli Indonesia yang apabila Indonesia tidak siap menerima perubahan globalisasi, maka bukan tidak mungkin akan cenderung memudarnya nilai-nilai kelestarian budaya.

Artikel tradisi tiba meka orang Manggarai ini diharapkan dapat memperkaya literasi budaya Indonesia terkait dengan nilai-nilai kearifan lokal dan nilai-nilai karakter yang terkadung di dalamnya.

\section{HASIL DAN PEMBAHASAN}

Kajian tentang ritual tiba meka orang Manggarai sebagai bentuk tata cara penyambutan tamu yang mengunjungi suatu kampung atau wilayah atau instansi tertetu 
dengan tradisi yang berlaku umum bagi masyarakat Manggarai. Ritus tiba meka tidak terlepas dari nilai-nilai karakter yang dianut oleh masyarakat Manggarai dalam sikap dan berperilaku dalam kehidupan sehari-hari.

\section{Kearifan Lokal}

Masyarakat Indonesia yang terdiri dari beragam suku dan bahasa tentu memiliki nilai-nilai niai-nilai kearifan lokal yang membentuk karakter perilaku masyarakat yang mendiami suatu wilayah tertentu. Kearifan lokal (local wisdom) merupakan pandangan hidup, ilmu pengetahuan, dan berbagai strategi kehidupan yang berwujud aktivitas yang dilakukan oleh masyarakat setempat untuk menjawab berbagai masalah dalam pemenuhan kebutuhan mereka. Disamping itu, kearifan lokal dapat pula dimaknai sebagai sebuah sistem dalam tatanan kehidupan sosial, politik, budaya, ekonomi, dan lingkungan yang hidup di dalam masyarakat lokal. Karakter khas yang inherent dalam kearifan lokal sifatnya dinamis, kontinu, dan diikat dalam komunitasnya (Wagiran, 2011: 85).

Dalam hal ini, kearifan lokal berdasarkan pandangan Wagiran di atas, memiliki beberapa konsep, diantaranya (1) kearifan lokal adalah sebuah pengalaman panjang, yang diendapkan, sebagai petunjuk perilaku seseorang, (2) kearifan lokal tidak lepas dari lingkungan pemiliknya, (3) kearifan lokal itu bersifat dinamis, lentur, terbuka, dan senantiasa menyesuaikan dengan jamannya. Konsep demikian juga sekaligus memberikan gambaran bahwa kearifan lokal selalu terkait dengan kehidupan manusia dan lingkungannya. Kearifan lokal muncul sebagai penjaga atau filter (tameng) iklim global yang melanda kehidupan manusia.

Nilai-nilai kearifan lokal yang ada di Indonesia terbukti turut menentukan kemajuan masyarakatnya. Beberapa contoh misalnya: (1) nilai yang terkandung dalam semboyan "heuras peureupna, pageuh keupeulna tur lega awurna" telah mampu memotivasi orang Sunda untuk tampil sebagai pekerja keras dan wirausaha handal; (2) nilai-nilai " Adek Pangadereng" menjadikan orang-orang Wajo sangat menghormati, menjunjung tinggi hukum, hak asasi manusia dan pemerintahan yang demokratis; (3) semboyan "Oreng Madura ta' tako' mateh, tapeh tako` kalaparan` telah mengantar orang-orang Madura menjadi perantau dan pekerja keras; (4) sistim Subak di Bali tidak hanya menjadikan masyarakat Bali menjadi masyarakat yang rukun dan damai, tetapi juga menjadi masyarakat yang pandai mengatur sistem ekonomi dan pertanian; (5) budaya "sasi" di Maluku, "tara bandu" di Papua atau yang dikenal di Jawa sebagai "pranata mangsa" tidak hanya berperan dalam pelestarian lingkungan, tetapi lebih jauh mampu mempertahankan keselarasan hubungan manusia dengan alam, keselarasan hidup dan pemanfaatan sumberdaya alam secara lebih arif.

Kajian tentang kearifan lokal dapat dikaji dari filosofi orang Manggarai itu sendiri yang meliputi: Pohon, Bangunan, Pemerintahan, Kepemimpinan, Simbolisme Binatang, Simbol Vegetasi, Simbol senjata. Sedangkan dari sisi budaya, secara komprehensif dapat dicermati dari tata nilai budaya Manggarai yang meliputi aspek: (1) Religio-spiritual, (2) Moral, (3) Kemasyarakatan, (4) Adat dan tradisi, (5) Pendidikan dan pengetahuan, (6) Kesenian, (7) Bahasa. Sumber kearifan lokal yang lain dapat berupa lingkaran hidup orang Manggarai yang meliputi: upacara Penti, upacara kelahiran, congko lokap, wagal (perkawinan), dan kematian. Berbagai macam local wisdom tersebut merupakan potensi pengembangan pendidikan berbasis kearifan lokal yang mengarah kepada pembentukan karakter. Itulah sebabnya, dunia pendidikan perlu segera merancang, menentukan model yang paling tepat untuk melakukan penyemaian kearifan lokal. Kearifan lokal dapat menjadi corong pendidikan karakter yang humanis. Kearifan lokal secara substansial merupakan nilai-nilai 
yang berlaku dalam masyarakat, baik secara eksplisit maupun implisit diyakini kebenarannya menjadi acuan dalam bertingkah laku dalam kehidupan sehari-hari di masyarakat. Kearifan lokal memiliki nilai-nilai yang mampu mempengaruhi pilihan yang tersedia dari bentuk-bentuk, cara-cara, dan tujuan-tujuan tindakan secara berkelanjutan; mengikat setiap individu untuk melakukan suatu tindakan tertentu; memberi arah dan intensitas emosional serta mengarahkan tingkah laku individu dalam situasi sehari-hari.

\section{Makna Tiba Meka}

Makna tiba meka berasal dari dua kata yaitu tiba dan meka. Tiba berarti terima, menadah, tangkis, setuju atau menyambut sedangkan meka berarti tamu (Verheijen: 1967:350). Jadi, tiba meka berarti menerima atau menyambut tamu. Anak yang baru lahir disebut meka weru (tamu yang baru dilahirkan).

Dalam kehidupan sehari-hari orang Manggarai, ada beberapa maksud kedatangan tamu dalam sebuah kampung atau beo (Pandor, 2014: 210). Pertama, meka lako lejong, meka lako liba (tamu yang secara kebetulan mampir di suatu kampung) yaitu mereka yang melintasi sebuah kampung untuk menjual barang-barang dagangan (meka ata pika barang), untuk mencari kuda atau kerbau (meka ata kawe kaba agu jarang), dan untuk sekadar minum (meka ata masa wae). Kedua, meka ata poli reke be olon (tamu yang terlebih dahulu berjanji untuk datang ke suatu kampung). Meka jenis kedua ini adalah mereka yang datang ke sebuah kampung karena ada keperluan seperti tamu pemerintah, tokoh agama, atau lembaga sosial kemasyarakatan yang memang datang karena ada urusan yang terkait dengan urusan keluarga atau kampung yang bersangkutan. Ketiga, meka lejong toe reke (tamu yang datang tanpa pemberitahuan) seperti mereka yang menjadi petualang atau sekadar rekreasi. Dari tiga jenis tamu berdasarkan tujuannya di atas, yang biasanya diterima secara adat adalah meka ata poli reke be olon (tamu yang sudah berjanji untuk datang ke suatu kampung/beo). Tamu yang termasuk dalam bagian ini pun, dikelompokkan lagi ke dalam beberapa jenis. Pertama, meka ata undang lite (tamu yang diundang) dalam upacara adat seperti penti (syukur atas panen), randang, caci wagal (syukuran perkawinan), cear cumpe (upacara pemberian nama), dan sebagainya. Kedua, meka ata manga perlu agu ite (tamu yang ada perlu dengan kita), misalnya meka mai undang ite kudut ikut acara dise (tamu yang datang untuk mengundang kita untuk menghadiri acara mereka, anak rona mai sida (keluarga laki-laki pihak istrimeminta dukungan dan doa dan dukungan), anak wina lamar anak dite (keluarga yang datang melamar anak perempuan kita) dan sebagainya. Ketiga, meka pemerintah atau tokoh agama dan masyarakat. Biasanya mereka ini datang untuk memberi dukungan material maupun spiritual demi kemajuan sebuah kampung.

Kajian yang relevan dengan ritual tiba meka orang Manggarai adalah kajian yang ditulis oleh Pius Pandor (2015) dengan judul menyambut dan memuliakan sesama dalam ritus inisisai sosial tiba meka orang Manggarai. Gagasan dasarnya adalah menggali nilainilai kemanusiaan beradab yang terkandung dalam ritus inisiasi sosial orang Manggarai yaitu tiba meka. Penelitian yang dilakukan oleh Sabina Ndiung (2017) dengan judul ritus tiba meka orang Manggarai dalam kajian etnopedagogi. Nilai-nilai pendagogi yang berhasil digali atau dianalisisdari ritus tiba meka adalah nilai filosofis, nilai antropologis, nilai sosiologis, dan nilai psikologis. Nilai-nilai tersebut perlu dihidupi atau dihayati oleh orang Manggarai. Dengan demikian, pesona yang terkandung dalam ritus tiba meka memberi kekuatan dan motivasi bagi setiap orang untuk menjadi manusia yang baik, benar dan beriman. 


\section{Nilai-Nilai Karakter}

Sikap dan perilaku masyarakat dan bangsa Indonesia akhir-akhir ini cenderung mengabaikan nilai-nilai luhur yang sudah lama dijunjung tinggi dan mengakar dalam sikap dan perilaku sehari-hari. Sikap acuh tak acuh, sombong, dengki, iri hati, cemburu, munafik, tidak ramah, dan lainnya sering dijumpai dalam kehidupan sehari-hari. Antara orang yang satu dengan yang lainnya tidak lagi ada sikap saling tegur sapa ataupun saling menghargai. Nilai-nilai karakter mulia, seperti kejujuran, kesantunan, kebersamaan, dan religius, sedikit demi sedikit mulai tergerus oleh budaya asing yang cenderung hedonistik, materialistik, dan individualistik, sehingga nilai-nilai karakter tersebut tidak lagi dianggap penting. Salah satu upaya ke arah itu adalah melakukan pembinaan karakter di semua aspek kehidupan masyarakat, terutama melalui institusi pendidikan dan juga tradisi dan nilai-nilai kearifan lokal masyarakat setempat.

Secara etimologis, kata "karakter" diartikan dengan tabiat, sifat-sifat kejiwaan, akhlak atau budi pekerti yang membedakan seseorang dengan yang lain, dan watak. Karakter juga bisa berarti huruf, angka, ruang, simbul khusus yang dapat dimunculkan pada layar dengan papan ketik (Pusat Bahasa Depdiknas, 2008: 682). Orang berkarakter berarti orang yang berkepribadian, berperilaku, bersifat, bertabiat, atau berwatak. Dengan makna seperti ini berarti karakter identik dengan kepribadian atau akhlak. Kepribadian merupakan ciri atau karakteristik atau sifat khas dari diri seseorang yang bersumber dari bentukan-bentukan yang diterima dari lingkungan, misalnya keluarga pada masa kecil, dan juga bawaan sejak lahir (Koesoema, 2007: 80).

Secara terminologis, makna karakter dikemukakan oleh Thomas Lickona. Menurutnya karakter adalah "a reliable inner disposition to respond to situations in a morally good way." Selanjutnya Lickona menambahkan, "Character so conceived has three interrelated parts: moral knowing, moral feeling, and moral behavior" (Lickona, 1991: 51). Menurut Lickona, karakter mulia (good character) meliputi pengetahuan tentang kebaikan, lalu menimbulkan komitmen (niat) terhadap kebaikan, dan akhirnya benar-benar melakukan kebaikan. Dengan kata lain, karakter mengacu kepada serangkaian pengetahuan (cognitives), sikap (attitides), dan motivasi (motivations), serta perilaku (behaviors) dan keterampilan (skills).

Menurut Azra (2012), faktor agama, budaya dan pendidikan sangat berhubungan erat dengan nilai-nilai yang sangat penting bagi manusia dalam berbagai aspek kehidupannya. Budaya atau kebudayaan umumnya mencakup nilai-nilai luhur yang secara tradisional menjadi panutan bagi masyarakat. Pendidikan selain mencakup proses transfer dan transmissi ilmu pengetahuan juga merupakan proses sangat strategis dalam menanamkan nilai dalam rangka pembudayaan anak manusia. Sementara itu, agama juga mengandung ajaran tentang berbagai nilai luhur dan mulia bagi manusia untuk mencapai harkat kemanusiaan dan kebudayaannya.

Dari pengertian di atas dapat dipahami bahwa karakter identik dengan akhlak, sehingga karakter merupakan nilai-nilai perilaku manusia yang universal yang meliputi seluruh aktivitas manusia, baik dalam rangka berhubungan dengan Tuhannya, dengan dirinya, dengan sesama manusia, maupun dengan lingkungannya, yang terwujud dalam pikiran, sikap, perasaan, perkataan, dan perbuatan berdasarkan norma-norma agama, hukum, tata karma, budaya, dan adat istiadat. 


\section{Tata Cara Tiba Meka}

Dalam penyambutan tamu (tiba meka) orang Manggarai melalui prosedur-prosedur tertentu. Adapun tata cara tiba meka yang digunakan hingga saat ini dan didukung oleh penelitian Ndiung pada tahun 2017 adalah sebagai berikut.

\section{Reis tiba di'a (penyambutan dengan baik)}

Dalam bagian Reis tiba di'a ini, ada tiga hal yang kiranya perlu diperhatikan. Pertama, sapaan pembukaan. Bagian ini disebut sebagai pengantar untuk membuka acara penerimaan tamu. Pengantar ini disampaikan oleh salah satu perwakilan dari anggota yang mendiami sebuah kampung. Biasanya dipilih dari salah satu anggota kampung yang bisa menjadi penutur adat atau pemuka masyarakat yang berfungsi sebagai laro jaong (juru bicara) dan letang temba (mewakili) warga kampug. Kedua, Ungkapan kegembiraan. Bagian ini menunjukkan kegembiraan warga kampung karena mereka melihat tamu telah datang. Ungkapan kegembiraan (naka) itu diwakili oleh penutur adat dengan kata kapu (memangku). Selanjutnya penutur adat mengungkapkan kekaguman kepada sang tamu yang bersedia datang ke sebuah kampung dengan penuh perjuangan. Dia harus melewati sungai, gunung dan lembah. Hal ini menunjukkan cinta dan perhatian sang tamu terhadap semua warga yang mendiami sebuah kampung. Ketiga, Penutup. Dalam bagian ini, tamu diberi ayam jantan berwarna putih dan tuak (dalam kondisi tertentu bisa menggunakan bir) sebagai puncak kegembiraan dari warga kampung yang diwakili oleh penutur adat sebagai tanda kehormatan. Di sini tuak menjadi lambang penyerahan seluruh harapan kepada tamu yang datang untuk bergembira bersama semua warga kampung.

\section{Raes agu raos cama laing (berbagi suka cita dan kebersamaan)}

Dalam bagian kedua ini ada tiga bagian penting yang kiranya perlu diperhatikan. Pertama, Sapaan. Dalam bagian ini penutur adat menyebut tamu yang datang dengan ema. $\mathrm{Hal}$ ini tentu menandakan bahwa budaya patriarkal sangat kental dalam budaya Manggarai. Dalam sapaan ini, penutur adat juga menunjukkan kerendahan hati dengan melukiskan situasi kampung yang dihuni oleh manusia yang tidak memiliki pengetahuan yang luas dan mendalam. Kedua, suasana keakraban. Dalam bagian ini, penutur adat menampilkan suasana yang melukiskan keakraban sang tamu dengan semua warga kampung. Suasana keakraban ini sangat nampak dalam kesatuan warga kampung untuk berkumpul (padir wai rentu sai) menyambut tamu yang datang. Ketiga, simbol penerimaan. Dalam bagian ini, penutur adat memberikan tuak reis (tuak penyambutan) sebagai ajakan bagi tamu untuk menjadi bagian dari warga kampung dan menikmati suasana kegembiraaan.

\section{Pandeng cepa (kebersamaan jasmani dan rohani)}

Dalam bagian ketiga, acara pandeng cepa. Acara pandeng cepa lebih pada tindakan pemberian sirih pinang tanpa ada pernyataan formal adat. Dalam kebiasaan orang Manggarai, yang berperan untuk memberikan siri pinang adalah kaum perempuan. Meskipun tanpa pernyataan adat, pandeng cepa sarat dengan makna simbolis. Dalam adat Manggarai setelah menyapa tamu, pertama-tama diberikan sirih pinang. Sirih pinang dipakai dalam kebudayaan orang Manggarai sebagai reis (ucapan selamat datang secara simbolis). Dalam reis tersebut, sirih dan pinang dicampur dengan kapur sirih yang dalam pemakaiannya tidak segera habis, tetapi tetap disimpan dalam wadah khusus. Kapur sirih inilah yang menghasilkan warna dan tahan lama. Hal ini mau menyimbolkan bahwa persaudaraan bagi orang Manggarai tetap terjalin dan tidak terputus. Sama halnya dengan 
tuak, sirih pinang juga menyimbolkan persekutuan dan keakrabatan. Menikmati sirih pinang adalah tanda masuk dan mengecap suasana persekutuan.

\section{Inung Waekolang (Minum bersama sebagai tanda keakraban)}

Setelah pemberian siri pinang, baru disuguhkan wae kolang (air panas) sebagai minuman pembuka. Inung wae kolang merupakan kebiasaan penting orang Manggarai. Setiap kali orang bertamu, selalu disuguhkan minuman. Haram sifatnya kalau tamu tidak disuguhkan wae kolang. Wae kolang (air panas) sesuai dengan sifatnya di mana air yang disuguhkan bukan air dingin, melainkan air yang panas. Meskipun, orang sudah minum air dingin karena kehausan, itu belum cukup dan tidak menggambarklan kebiasaan orang Manggarai. Air panas merupakan bagian dari kebiasaan penerimaan tamu. Wae kolang merupakan ungkapan untuk menggambarkan suguhan pembuka. Bukan hanya air yang disuguhkan, melainkan juga makanan ringan, bahkan juga nasi, sayur, dan lauk. Artinya menu yang disuguhkan ketika orang baru tiba, berupa makanan dan minuman sebagai menu pembuka disebut dengan wae kolang.

\section{Tegi reweng (meminta peneguhan/motivasi)}

Dalam bagian kelima ini, ada tiga hal yang kiranya perlu diperhatikan. Pertama, sapaan. Seruan pembukaan yo ema merupakan sapaan terhormat terhadap tamu yang datang. Seruan ini di satu sisi menunjukan kebesaran tamu yang datang dalam kemegahan dan kekuasaan. Namun di sisi lain melukiskan situasi yang serba terbatas dalam suatu kampung. Situasi ini menurut penutur adat bisa membuat tamu canggung dan kurang bersahabat dengan warga kampung yang menunjukkan muka muram. Kedua, Pengakuan. Pada bagian ini penutur adat menyampaikan dengan terus terang situasi aktual yang dihadapi oleh warga kampung yaitu mereka tidak bisa membaca surat (toe nganceng baca surak) dan malas (ngonde) untuk bekerja. Bagian ini memerlihatkan problem nyata yang dihadapi oleh masyarakat kampung yaitu pendidikan dan mentalitas kerja. Ketiga, penutup. Bagian ini penutur adat ingin menyampaikan kepada sang tamu agar bisa memberi beberapa pandangan positif demi kemajuan sebuah kampung. Sebagai penguat permintaan, penutur adat memberikan wejangan tuak kepada sang tamu. Dengan demikian, ia akan penuh semangat memberi yang berguna bagi peningkatan taraf hidup bagi masyarakat kampung.

\section{Wali di'a (mohon keselamatan untuk tamu)}

Dalam bagian keenam ini, ada empat hal yang perlu diperhatikan. Pertama, sapaan terima kasih. Dalam bagian ini, penutur adat menyapa sang tamu dengan penuh hormat. Dalam sapaan ini, penutur adat yang mewakili warga kampung menyampaikan ucapan terima kasih karena sang tamu bersedia mengunjungi dan bergembira bersama mereka. Kedua, harapan. Dalam bagian ini, penutur adat mengharapkan agar tamu diberi kelancaran dalam usaha dan umur panjang sehingga bisa berjumpa kembali dengan warga kampung. Bagian ini memerlihatkan pola kehidupan warga kampung yang selalu mengharapkan orang lain menerima kebaikan-kebaikan seturut apa yang dikerjakannya. Ketiga, permohonan maaf. Dalam bagian ini, penutur adat menyampaikan permohonan maaf kepada sang tamu. Isinya adalah jika ada kata-kata dan tindakan yang salah mohon tidak diingat dan disimpan di dalam hati. Keempat, penutup. Dalam bagian ini, penutur adat memberi penguat terhadap apa yang dikatakannya dengan tuak. Namun bukan tuak biasa tetapi tuak baro sala (tuak untuk minta dimaafkan). Dengan adanya maaf warga kampung terus terus mengenang saatsaat kegembiraan bersama sang tamu dan nasihat-nasihat yang diberikannya. 


\section{SIMPULAN}

Setiap tahap dalam penerimaan tamu yang telah diuraikan pada bagian pembahasan, mengandung nilai karakter bagi orang Manggarai sendiri dan tamu yang datang. Nilai-nilai karakter tersebut adalah keterbukaan, keakraban, kerendahan hati, kehormatan, tanggung jawab, kepedulian, dan sopan santun. Nilai-nilai ini ditanam melalui budaya saling menyapa sesama dalam berbagai situasi juga dalam bentuk kepedulian terhadap sesama serta berbagi kebahagiaan. Dalam proses menginternalisasikan nilai tersebut, peran tua adat sangat penting. Penting karena tua adat berfungsi sebagai laro jaong dan letang temba yaitu sebagai juru bicara dan perantara (mewakili) warga yang ada dalam satu kampung dengan tamu yang datang. Namun tidak semua tamu diterima secara adat. Tamu yang biasanya diterima secara adat adalah tamu kehormatan seperti tokoh pemerintah, tokoh masyarakat dan tokoh agama yang datang untuk semua warga kampung.

\section{DAFTAR PUSTAKA}

Azra, A. (2012) Pendidikan karakter teguhkan pribadi bangsa. Makalah. Disajikan di UNNES, Minggu 23 September 2012. Semarang.

Kartawinata, A. M. (2011) Meretas kearifan lokal di tengah modernisasi dan tantangan pelestarian dalam Nasruddin (2011). Kearifan Lokal di Tengah modernisasi. Jakarta: Pusat Penelitian dan Pengembangan Kebudayaan Badan Pengembangan Sumber Daya Kebudayaan dan Pariwisata.

Koesoema, A. D. (2007) Pendidikan karakter: strategi mendidik anak di zaman global. Jakarta: Grasindo. Cet. I.

Lasmawan, W. I (2016) Perspektif global dan problematika pendidikan dasar. Singaraja: Mediakom Indonesia.

Lickona, T (1991). Educating for character: how our school can teach respect and responsibility. New York, Toronto, London, Sydney, Aucland: Bantam books.

Ndiung, S. (2017). Ritus tiba meka orang manggarai dalam kajian etnopedagogi. The 1st International Conference on Language. Proceedings. http://publikasiilmiah.ums.ac.id

Pandor, P. 2015 menyambut dan memuliakan sesama dalam ritus tiba meka orang manggarai, dalam armada riyanto, dkk. kearifan lokal pancasila: butir-butir filsafat keindonesiaan. Yogjakarta: Kanisius

Pusat Bahasa Departemen Pendidikan Nasional (2008). Kamus Bahasa Indonesia. Jakarta: Pusat Bahasa. Cet. I.

Suwarta, T. H (2019). Ritual tiba meka menyambut Presiden Jokowi di Labuan Bajo. Retrieved from http://mediaindonesia.com.

Riyanto, A. dkk. 2015. Kearifan Lokal Pancasila: Butir-butir Filsafat kelndonesiaan. Yogjakarta: Kanisius

Sarbaini. 2015. Rekonstruksi Nilai-nilai baiman, bauntung, batuah. milik urang banjar perspektif etnopedagogi: Paper in International seminar on Etnopedagogy, November 14, 2015. Faculty of teacher training and eduation lambung Mangkurat university.

Verheijen, J. A. 1967. Kamus Manggarai -Indonesia, S-Gravenhage-Martinus Nijhoff, Belanda.

Wagiran. 2011. Pengembangan model pendidikan kearifan lokal dalam mendukung visi pembangunan DIY 2020. Jurnal Penelitian dan Pengembangan, 3(3), 85-100. 